\title{
The Job Analysis of Teaching Secretaries Working in an International Environment --- Taking Jinan University, Guangzhou, China as the Research Paradigm
}

\author{
$\mathrm{Li} \mathrm{Jia}^{1}$ \\ ${ }^{1}$ International School, Jinan University, Guangzhou, China \\ Correspondence: Li Jia, R318, the second Social Sciences Building, Jinan University, NO. 601 Huangpu Road \\ West, Guangzhou, Post Code: 510632, Tianhe District, Guangzhou City, Guangdong Province, China. Tel: \\ 86-0150-1308-2906. E-mail:53004098@qq.com
}

Received: April 27, 2017

Accepted: May 2, 2017 Online Published: May 31, 2017

doi:10.5539/ass.v13n6p181

URL: https://doi.org/10.5539/ass.v13n6p181

The paper reported here is sponsored by the project of 2016 Guangzhou Philosophy and Social Science "the 13th Five-Year Plan", Project name: Research on the Cultivation of Craftsman Spirit and Career Identity of College Students, Project Grant No.: 2016MZXQ01.

\begin{abstract}
Under the guidance of national policy, Chinese higher education institutions use English as teaching language. With this feature, an international environment is formed that the university offers places to eligible students from all over the world and employs qualified teachers from all over the world to teach students. Working in an international environment, the teaching secretaries' job is different. This paper analyzes the job particularity of teaching secretaries working in an international environment in higher education institutions that their working language is English and they have to work with teachers and students from all over the world, answer teachers and students questions and solve their problems related to teaching affairs. This paper proposes some effective measures from the personal aspect and university aspect to raise the quality of the teaching secretaries' job. And this paper gets a conclusion that the teaching secretaries working in an international environment should increasingly improve their comprehensive quality, professional knowledge, and management skills.
\end{abstract}

Keywords: international working environment, teaching secretaries in higher education institutions, job analysis

\section{Introduction}

In 2001, the Chinese Ministry of Education proposed that attempts should be made to use English as a teaching language in major courses and common required courses of undergraduate education. Under the guidance of this principle, universities implemented the use of English as a teaching language for undergraduates. Jinan University, Guangzhou, China (JNU) established its International School using English as the medium of instruction in 2001 and one of their stated aims was to cultivate students all over the world who can speak English to become professional talents. With this special feature and international teachers and students, JNU International School's environment is very international. Right now, they have 9 undergraduate majors: International Economics and Trade, Accounting (CPA Canada), Clinical Medicine, M.B.B.S. (Bachelor of Medicine and Bachelor of Surgery), Food Quality and Safety, Pharmacy, Finance, Computer Science and Technology, and International Journalism. Also, they have 1 master program of China Studies.

With the reform in education, teaching management has had to change. Teaching secretaries play an important role in education management. Especially, working in an English teaching and international environment, the secretaries have to face new challenges, and they require new skills to adapt to the environment. Thus, we have to discuss how these secretaries can adapt to the environment of using English as a working language; and how they can improve their work quality and efficiency to increasingly upgrade the education management level.

2. The particularity of Education Administration Secretaries' Job as Serving International Teachers and Students

University teaching secretaries are the people who work in the schools or colleges to assist school leaders and 
the university academic department deal with issues related to teaching affairs and ensure the daily teaching operates smoothly. They are an indispensable part of a university's teaching management. The duties of teaching secretaries working in an international environment are almost the same as secretaries working in other schools or colleges. However, since they are working in a special environment that uses English to teach, and as they serve many international teachers and students, their jobs are different from secretaries in other schools or colleges. The job of teaching secretaries working in an international environment has these features:

\subsection{The teaching secretaries should adapt to the international environment and use English as a working language to communicate with international students and teachers.}

Jinan University, Guangzhou, China operates on one of the principles that they always recruit overseas Chinese students. The students' backgrounds are diversified. There are international students (including exchange students), Hong Kong and Macau students, overseas Chinese students (these three kinds of students are referred to as non-mainland students) and Chinese students from mainland China (these kinds of students are referred to as mainland students). The International School of JNU aims to use English as a teaching language to teach students and instruct them to do experiments and internships. With this special feature, international school students come from 86 countries (the latest statistics are from 2017) all over the world and they all use English to communicate with each other. According to the statistics, $77 \%$ of students are non-mainland students in the International School, $21 \%$ of these are overseas Chinese students, and $41 \%$ are Hong Kong and Macau students. International students' speak English. Overseas Chinese students come from all over the world, including some small island states, and in most cases, they speak English fluently; also most can understand and speak Chinese but don't know how to write Chinese characters. The mother tongue of Hong Kong and Macau students is Cantonese and those from Taiwan speak Chinese, however, the popularity of English is very high; in most cases, they can speak and understand English. Mainland students who win the admission offer to JNU all received very competitive scores in the college entrance examination; in most cases, they also speak and understand English. The diversified students' backgrounds push the teachers to use English to teach knowledge and drives teaching secretaries to use English to answer international students' questions and communicate with students. Also, all the notices they send out have to be written in English to make sure all the students understand. Thus, English becomes very important and the first working language for the teaching secretaries. According to the statistics, there are almost 20-30 international teachers who work in JNU International School to teach several courses as either long term teachers or as short term, 1 course only teachers in a semester. The teaching secretaries are required to communicate with all the international teachers to arrange their course schedules, final exam schedules and other issues related to teaching. Moreover, students will give teachers' teaching result feedback to the academic administration office, and then the staff, acting as a bridge between teachers and students, has to make suggestions to teachers. International teachers also speak English. Right now, Chinese is still the main teaching language and working language in most of the Chinese higher education institutions; people all communicate with each other in Chinese. So, all the academic documents, notices and website interfaces are written in Chinese. The teaching secretaries have to translate or interpret the documents and notices into English to make sure all the international students and teachers get the point. This workload is large, but they have to do it to make sure everything works smoothly. Hence, English is the very important working language. This also requires the teaching secretaries have a good command of English, not only in writing but also in speaking, listening, translating and interpreting.

2.2 Since the implementation of the credit system in higher education institutions, the teaching secretaries work as important academic advisors for students to ensure they carry out their major study plan step by step and satisfy the graduation credits requirement.

The credit system refers to a teaching management system where students select their courses according to their major training plan; they have a required number of credits to complete before they can graduate. According to statistics, more than 200 higher education institutions in China implemented the credit system. These include most of the national key universities. As part of the implementation of the credit system, students had flexibility in course selection in that they could select their major compulsory courses, and their favorite elective courses. Once they had completed all their courses and finished their internship within the required valid time, then they could get their graduation certificate and degree certificate. The maximum valid time enrolled as a JNU student is 8 years. Most students graduate after 4 years. Some of the students may suspend their study for 1 semester or 1 year to enrich their experiences by carrying out an innovation and entrepreneurship program or exchanging to another university abroad. JNU International School also implements the credit system. However, it is sometimes hard for first year students to adapt to the brand new university life and some students do not fully understand the credit system, some even do not know how to use the JNU system to select courses. At this 
moment, when students face all these complicated issues, the teaching secretaries must assist students to help them solve all the academic problems they encounter. Since the JNU system website interface is in Chinese, the teaching secretaries will devote a lot of time to help students select courses, especially international students. Each semester, the teaching secretaries has to help the international students review their courses one by one according to their major training plan and make sure they carry out the plan step by step, in case any course is missing, as this mistake could mean that they might not graduate in time. To this degree, the teaching secretaries support the students' course selection.

\section{The Effective Measures to Raise the Quality of the Teaching Secretaries' Job}

\subsection{One of the measures is to promote the ideological and ethical standards and comprehension in ideology and politics}

The teaching secretaries, working in an international environment, communicate with international teachers and students every day. This very special situation requires academic administration staff have strong political beliefs, good virtues and morality. No matter what happens, they have to believe that their motherland's honor is higher than everything! The teaching secretaries should never say or do anything that harms the image of our motherland and they will stand out forthwith to denounce and respond to those rumors and actions in the campuses that have blemished China's image and reputation.

\subsection{One of the measures is to strengthen the professional ethics quality}

It is said in Wikipedia that "professional ethics encompasses the personal, organizational, and corporate standards of behavior expected by professionals. Professionals and those working in acknowledged professions exercise specialist knowledge and skill. How the use of this knowledge should be governed when providing a service to the public can be considered a moral issue and is termed professional ethics". ${ }^{1}$ With complex job content, the teaching secretaries who have to strengthen professional ethics should be very careful and always follow the university rules and regulations to do everything and be impartial to every student, no matter where they come from. Moreover, the teaching secretaries should be very patient to every student, no matter how many questions they have.

\subsection{One of the measures is to improve the professional knowledge of academic administration staff}

The effective way to improve professional knowledge is to insist on being a lifelong learner, acquire new knowledge, and follow the development of the times. The teaching secretaries working in an international environment has to learn the rules and regulations of the university to advise the teachers and students to do everything to follow the rules, plus they have to learn each major training plan to provide the guidelines of students' study plans semester by semester. The teaching secretaries have to learn the theoretical knowledge of education management to apply theory into practice and improve the management methods in practice. They also have to insist on learning the advanced education management concept of overseas universities to improve the current rules of education management. When working with many international teachers and students, the teaching secretaries has to know about religious taboos and respect everyone to avoid disputes happening. In addition, the teaching secretaries working in an international environment should insist on learning English to enhance their English proficiency, including their listening, speaking, writing, reading, translating and interpreting skills.

\subsection{One of the measures is to improve their communication and coordination ability}

JNU International School operates 9 undergraduate majors, which are International Economics and Trade, Accounting(CPA Canada), Clinical Medicine, M.B.B.S.(Bachelor of Medicine and Bachelor of Surgery), Food Quality and Safety, Pharmacy, Finance, Computer Science and Technology and International Journalism, together with1 master program: China Studies, in association with the major schools or colleges. Two of the majors, Accounting (CPA Canada) and M.B.B.S. (Bachelor of Medicine and Bachelor of Surgery) are taught in cooperation with enterprises. JNU International School plays a role as a management platform that is responsible for communicating with teachers in all major schools or colleges to arrange each major's courses schedule for each semester, since there aren't enough teachers who teach students courses related to their majors. The advantage of JNU International School as a management platform is that all the teaching resources are well integrated and all the major students could share the same elementary courses. JNU doesn't introduce any software to arrange course schedules. The entire job has to be done by the teaching secretaries in their own schools or colleges. According to the statistics, the teaching secretaries working in JNU international School has

${ }^{1}$ Definition from Wikipedia, https://en.wikipedia.org/wiki/Professional_ethics 
to communicate with almost 300 teachers every semester to arrange the major course schedules. To date, there are 1736 students registered this semester that the teaching secretaries have to provide professional help to in their study, course selection and so on. Moreover, the teaching secretaries have to communicate with enterprise staff to communicate the students' study, text books and all the issues encountered when operating the major. Also, the teaching secretaries have to report to the academic department of the University regarding job duties and they have to follow the specified schedule to hand in documents to them. This huge workload requires the teaching secretaries have very good communication and coordination abilities, and that they follow the rules and regulations, but can be flexible and responsive when dealing with unexpected situations. The teaching secretaries should try their best to create a friendly atmosphere to do the job effectively. They should subordinate themselves to those in higher levels, coordinate with colleagues and answer students and teachers questions patiently.

3.5 One of the measures is to introduce modernization to become an informatization, networkization and digital working place.

With the rapid development of computer technology, its application has penetrated into all areas of social life and daily work. Increasing university enrollments means more and more students are admitted into the university. The traditional teaching management methods can't meet the new requirements, so the university should introduce the latest technological ways to realize the informatization, networkization and digital office to improve work efficiency. With the development of the educational administration system, the daily job has become more informatization and the teaching secretaries could use the system to arrange the course schedules, help all the students to register and even do everything related to teaching affairs in the system, which would be really convenient for all teaching secretaries. There are a lot of functions in the system, so the teaching secretaries should put a lot of effort into learning how to utilize it and learn computer network technology to realize the modernization of information management step by step. To date, the two most popular social media are Weibo and WeChat. Weibo is like Twitter, which is online news and social networking service where users post and interact with messages. WeChat is a social media (instant messaging, commerce and payment service) application developed by Tencent. According to Wikipedia, it was first released in 2011, and by 2016 it was one of the largest stand-alone messaging apps by monthly active users, with over 889 million active users ${ }^{2}$. We may say that most people, especially university students who have cellphones, have all installed Weibo and WeChat. So, it is suggested that the school or college in higher education institutions should open Weibo or WeChat accounts in the name of the school or college and appoint one teaching secretaries to operate the accounts. For example, the secretaries could make updates, announcements, publish news or events and interact with students in real-time. Weibo and WeChat are also places where people like to talk about whatever they like. Sometimes there maybe disputes between the teaching secretaries and students because of a misunderstanding, and then the student may write some offensive words in Weibo or WeChat. When facing the situation, the teaching secretaries shouldn't be angry with the student and also publish offensive words in Weibo or WeChat. Instead, they should be calm and then give a chance for each person to explain their side clearly to smooth away the misunderstanding. It is highly recommended that teaching secretaries learn modernization ways to make their own job become informationized, networked and digital to improve their work efficiency.

3.6 One of the measures is letting the university put a high value on the development of the team of teaching secretaries, organizing various training courses regularly and establishing a long-term system of promotion and encouragement

People do not fully understand the teaching secretaries' job content. They think the job is very easy and mainly deals with unimportant matters without high technical content. Each university has established an academic department, which is directly headed by the Vice President of the university. However, the teaching affairs office of the school or college is headed by the Vice Dean of the school. Sometimes, the university does not pay attention to the development of the team of teaching secretaries. This really influences the enthusiasm for the teaching secretaries' job. Right now, the teaching secretaries who are working in an international environment all have master's degrees and have graduated from overseas universities or universities in Hong Kong or Macau. The team is young with passion and eager to learn, but they also need to develop and progress. Their task is much heavier and the responsibility is much greater than the teaching secretaries of other schools and colleges where the working language is Chinese. The university should put a high value on the teaching secretaries' team construction. For example, the university should organize various training courses regularly to enhance their professional skills to improve their work efficiency. Right now, there are seldom incentive measures for teaching

${ }^{2}$ Information from Wikipedia, https://en.wikipedia.org/wiki/WeChat 
secretaries. In the situation as it exists now, it seems that there is only punishment for them. If anything goes wrong, the teaching secretaries will be punished by the university, which uses such means as deducting bonuses or taking away promotion chances in the following two to three years, which really has a bad effect on personal prospects. In this situation, the teaching secretaries do everything carefully, and are afraid of making any mistakes. This also influences their creativity and subjective initiative. Thus, it is vitally important that the university take incentive measures to encourage the teaching secretaries and establish a long-term system of promotion. Once incentive measures are in place, the teaching secretaries would work actively and effectively and devote themselves into creating a happy and fulfilling workplace. The teaching secretaries' potential also could be fully exploited and this would help them display their subjective initiative.

All in all, the teaching management level of the teaching secretaries working in an international environment is one of the symbols to evaluate the university's internationalization. To a certain degree, the teaching secretaries' work quality, which plays an important role in the university, directly has an impact on the management quality of the university. It is said that the teaching secretaries working in an international environment represents the national image, which is shown in everything they have done for the international students and teachers and in the daily communication they have to work with the international students and teachers. Thus, the teaching secretaries working in an international environment should increasingly improve their comprehensive quality, professional knowledge, and management skills. And they also should learn the advanced foreign management theory, apply theory into practice and devote themselves into their work and make valuable contributions to the teaching management of the university.

\section{References}

Han, H. Y., \& Zhao, Y. L. (2013).Discussion on Responsibilities and Qualities of Teaching Secretaries in Instructional Academic Departments, 2013 Fourth International Conference on Education and Sports Education (ESE 2013) (Vol 13, pp. 533-536),Hong Kong

Li, Y. F., \& Wang, H. C. (2016). Some Thoughts on the Teaching Secretaries in Colleges and Universities at present, Proceedings of the 2nd International Symposium on Social Science (ISSS 2016) (Vol43, pp. 356-360), Orlando, Florida

Professional ethics. In Wikipedia, the free encyclopedia. Retrieved from https://en.wikipedia.org/wiki/Professional_ethics

WeChat. In Wikipedia, the free encyclopedia. Retrieved from https://en.wikipedia.org/wiki/WeChat

Zhang, C. J. (2003). Innovative Talent Management and Development Mechanism Is the Only Road for Teaching Staff Construction in University. Theory and Practice of Education.

\section{Copyrights}

Copyright for this article is retained by the author(s), with first publication rights granted to the journal.

This is an open-access article distributed under the terms and conditions of the Creative Commons Attribution license (http://creativecommons.org/licenses/by/4.0/). 